простір". - Тернопіль: Укрмедкнига, 2009. - С. 89-91.

4. Макар Б. Г. Використання тестових технологій в умовах кредитно-модульної системи навчання / Б. Г. Макар, В. В. Кривицький // Матеріали Всеукраїнської навчальнонаукової конференції “Проблеми інтеграції української медичної освіти у світовий освітній простір”. - Тернопіль: Укрмедкнига, 2009.-С. 101-102.

5. Пашко К. О. Про створення спільної бази тестових завдань для всіх вищих медичних навчальних закладів України / Пашко К. О., Кашуба М. О., Максимова В. В. // Матеріали
Всеукраїнської навчально-наукової конференції “Проблеми інтеграції української медичної освіти у світовий освітній простір". - Тернопіль: Укрмедкнига, 2009. - С. 109-110.

6. Сирцов В. К. Новий освітній євростандарт: мультимедійні технології увикладанні гістології згідно з кредитномодульною системою / Сирцов В. К., Федосеєва О. В., Свтушенко В. М. // Матеріали Всеукраїнської навчально-наукової конференції “Проблеми інтеграції української медичної освіти у світовий освітній простір". - Тернопіль: Укрмедкнига, 2009. - С. 127-128.

УДК 811.161.2’271:61

\title{
ВИВЧЕННЯ КУЛЬТУРИ ПИСЕМНОЇ ДІЛОВОЇ МОВИ В КУРСІ УКРАЇНСЬКОЇ МОВИ (ЗА ПРОФЕСІЙНИМ СПРЯМУВАННЯМ) У ВИЩИХ МЕДИЧНИХ НАВЧАЛЬНИХ ЗАКЛАДАХ
}

В. Я. Юкало

Тернопільський державний медичний університет імені I.Я. Горбачевського

\section{LEARNING OF THE ART OF BUSINESS WRITING LANGUAGE IN THE COURSE "THE PROFESSIONAL UKRAINIAN LANGUAGE" AT HIGHER MEDICAL EDUCATIONAL ESTABLISHMENTS}

\author{
V. Ya. Yukalo
}

Ternopil State Medical University by I. Ya. Horbachevsky

\begin{abstract}
У статті окреслено зміст і місце теми 3 культури писемної ділової мови в курсі “Украӥнська мова (за професійним спрямуванням)” у вищих медичних навчальних закладах, наведено матеріали до занять.
\end{abstract}

The article adduces the significance of the lesson on the art of business writing language in the course "The Professional Ukrainian language" at Higher Medical Educational Establishments.

Вступ. У навчальні плани вищих медичних навчальних закладів 2009 р. введено курс "Українська мова (за професійним спрямуванням)”. Одним з його завдань, відповідно до типової програми, є навчити учнів сприймати, відтворювати, редагувати тексти офіційно-ділового стилю [1]. Нині відсутнє задовільне обгрунтування змісту і місця теми з культури писемної ділової мови в курсі “Українська мова (за професійним спрямуванням)” у медичних ВН3.

Основна частина. Мета нашого дослідження уточнити зміст і місце теми з культури писемної ділової мови у введеному 2009 р. в навчальні плани ме- дичних (стоматологічних) ВНЗ курсу "Українська мова (за професійним спрямуванням)".

Зазначимо, що читання і складання ділових документів, зокрема професійних, є одним з важливих елементів професійної діяльності медичного працівника. Ознайомлення майбутніх спеціалістів з основними поняттями діловодства, текстовими нормами ділового стилю є запорукою їхньої успішної професійної діяльності.

Зважаючи на важливість теми "Культура писемної ділової мови”, на її засвоєння треба виділити не менше 1 / 7 частини від обсягу мовного курсу. Це ста- 
новитиме 6-8 год аудиторних (практичних) занять, оскільки на вивчення всього курсу в чинному навчальному плані відведено 40 год аудиторних занять.

Пропонуємо розглянути питання про документ $\mathrm{i}$ текстові норми ділового стилю, класифікацію ділових документів, медичну документацію, ознайомити студентів із загальними вимогами до оформлення ділової документації. Важливо звернути увагу на схему внутрішньої роботи, яку доводиться здійснювати кожному під час складання документа, на вимоги державного стандарту щодо оформлення (виготовлення) службових документів, на особливості проходження документів, культуру читання документації.

Зокрема, слід висвітлити такий матеріал про медичну документацію.

Медична документація - сукупність документів - носіїв медико-статистичної інформації про стан здоров'я окремих осіб, різних груп населення, про обсяг, зміст та якість медичної допомоги і діяльність медичних установ.

В Україні медична документація є обов'язковою, єдиною та уніфікованою, застосовується для управління охороною здоров'я і планування організації діяльності з охорони здоров' я населення.

Медична документація складається із кількох десятків жанрів інтрапрофесійної та інтерпрофесійної комунікації: журнал, книга, щоденник, зошит, карта, історія, витяг з медичної карти, картка, справа, листок, протокол, акт, висновок, довідка, програма, направлення, відомість, звіт, список, повідомлення, паспорт, сертифікат, свідоцтво, посвідчення, етикетка, талон, путівка, рецепт, сигнатура та ін. Кожен із жанрів, у свою чергу, поділяється на підвиди. Зокрема, існують такі жанрові типи карт: медична карта стаціонарного хворого, медична карта амбулаторного хворого, карта розвитку новонародженого, санаторно-курортна карта, карта імунізації, контрольна карта диспансерного нагляду, статистична карта хворого, який вибув із стаціонару.

Складання медичної документації регулюється чинним стандартом, зафіксованим у таких нормативних виданнях:

- Збірник нормативно-директивних документів з охорони здоров'я. - 2001-2011.

- Медична облікова документація, щзо використовується в стаціонарах лікувально-профілактичних закладів. - К., 1999. - 110 с.

- Медична облікова документація, щзо використовується в поліклініках (амбулаторіях). - К., 1999. - 334 с. та ін.

Регулярно лікар складає такі документи: медична карта стаціонарного хворого, медична карта амбу- латорного хворого, витяг з медичної карти, санаторно-курортна карта, індивідуальна карта вагітної та породіллі, історія розвитку дитини, рецепт, направлення, медична довідка тощо.

Зазначену сферу обслуговує мова медичної документації - кодифікований різновид професійної мови медичних працівників, що задовольняє потреби офіційного спілкування в галузі охорони здоров' я. Для цього різновиду характерне використання особливої термінології або термінологізованих спеціальних засобів мови, специфічних синтаксичних конструкцій (стандартних формул, кліше), а також стійких термінологічних словосполучень, медичних термінів.

З допомогою мультимедійних технологій майбутніх лікарів можна ознайомити із формулярами-зразками основних медичних документів.

Головний акцент у цій темі треба робити на розвиток культури писемної ділової мови у вихованців, ознайомлення 3 нормою мови медичної документації, засвоєння мовних стереотипів ділової мови, виправлення типових помилок узастосуванні цих стереотипів.

Треба виконати вправи на виправлення типових порушень у вживанні стандартних формул, кліше, а також стійких термінологічних словосполучень, термінів в медичних документах, зокрема завдання на російсько-український переклад словосполучень 3 відмінною лексикою.

Не зайвою також буде вправа, побудована за методом “антидиктанту”: написати літературні відповідники до слів і словосполучень, в яких допущено типові порушення норми. Оскільки такі порушення майже завжди виникають під впливом російської мови, то біля ненормативного українського слова найкраще навести його російський відповідник. Студент, маючи перед очима російський термін і неправильний український варіант, зможе швидше відшукати український літературний відповідник. Така вправа має переваги над прямим перекладом з російської мови, тому що студенти під час іiі виконання вже знають ненормативний варіант і не називають його.

Цей вид вправ буде актуальним доти, доки в комунікаціях лікарів функціонуватимуть росіянізми. Щоб їх уникати - їх треба знати (точніше, їх знають і без такої вправи, але після їі виконання студенти хоча б знатимуть, що це росіянізми).

Не зайвим буде обговорити мовні поради із слововживання, вміщені в медичних виданнях [2, 3].

Після проведення таких видів робіт можна давати завдання відредагувати речення ділового стилю, скласти ділові документи.

Цікаві вправи із міжстильової трансформації, напр. прочитати розмову лікаря з пацієнтом під час прий- 
мання і викласти наведені в діалозі факти в офіційноділовому стилі як запис в медичній карті.

Під час вивчення культури писемної ділової мови також опрацьовуються питання правопису іншомовних слів, прізвищі географічних назв, узгодження числівників з іменниками, присудка з підметом, розділові знаки при відокремленнях, вставних конструкціях.

На заняттях обов' язково слід застосовувати загальномовні й медичні словники $[4,5,6]$, довідники з питань культури мови $[7,8]$.

\section{Лiтература}

1. Українська мова (за професійним спрямуванням) : програма курсу для вищих навчальних закладів, які здійснюють підготовкуфахівців за освітньо-кваліфікаційним рівнем бакалавра (спеціаліста, магістра медичного та ветеринарно-медичного спрямувань) / [уклад. С. В. Шевчук, І. В. Клименко]: додаток № 2 до наказу Міністерства освіти і науки України від 21 груд. 2009 р. № 1150.

2. Рубрика "Із мовних глибин” // Медична академія. 1998. - 31 трав.; 25 черв.; 27 серп.; 30 верес.; 1999.;-29 веpec. 2000. -28 січ.; 26 черв.

3. Цикл “Мовні поради” // Ваше здоров'я : медична газета України: Індекс 60965. -2002. -8 лют. -№ 5. -С. 10; 15 лют. № 6. -С. 14; 22 лют. -№ 7.-С. 14; 1 бер. -№ 8. -С. 14; 8 бер.№ 9. -С. 13; 12 квіт. -№ 14. -С. 13; 19 квіт--№ 15.-С. 14; 26 квіт. -№ 16.-С. 14; 10 трав. -№ 17.-С. 14; 17 трав.-№ 18. -С. 13; 24 трав. - № 19.-С. 12; 31 трав. -№ 20. -С. 13; 7 черв. -№ 21. -С. 14; 21 черв. - № 23. -С. 14; 28 черв. -4 лип. -№ 24. -С. 14; 5-11 лип. -№ 25. -С. 6; 2004. - 2-8 січ. -№ 1.-С. 15; 16-22 січ.
Висновок. Отже, тема з культури писемної ділової мови є важливим складником курсу “Українська мова (за професійним спрямуванням)" у вищих медичних навчальних закладах. Під час вивчення зазначеної теми треба гармонійно поєднувати засвоєння теоретичних відомостей про медичну документацію, мову медичної документації із процесом вироблення вмінь і навичок оперування специфічним мовним матеріалом.

-№ 2. - С. 14; 23-29 січ. - № 3. - С. 14; 24-30 верес. - № 37. С. 14; 1-7 жовт.-№ 38.-С. 14; 8-14 жовт.-№ 39.-С. 14; 15-21 жовт. - № 40. -С. 14; 22-28 жовт.-№ 41.-С. 14.

4. Російсько-український словник наукової термінології. Біологія. Хімія. Медицина / [C. П. Вассер, I. О. Дудка, В. І. Єрмоленко та ін.] ; редактор-лексикограф Л. О. Симоненко. - К. : Наук. думка, 1996. - 660 с.

5. Український орфографічний словник: близько 143000 слів / [уклад. : М. М. Пещакта ін.]. -К. : Довіра, 2002. - 1006 с.

6. Українсько-латинсько-англійський медичний тлумачний словник : близько 33000 термінів : у 2 т. - Львів : Видавнича спілка “Словник”, 1995. - Т. І : А - К. - XXXIX + 651 с.; Т. II : Л - Я. - 786 c.

7. Культура мови на щодень / за ред. С. Я. Срмоленко. К. : Довіра, 2000. - 169 с.

8. Жайворонок В. В. Українська мова в професійній діяльності / В. В. Жайворонок, В. М. Бріцин, О. О. Тараненко. К. : Вища школа, 2006. -431 с. 